\title{
Changes in the structure of wheat (Triticum aestivum L.) roots in varieties susceptible and resistant to infestation by Heterodera avenae Woll.
}

\author{
GRAŻYNA GRYMASZEWSKA, WŁADYSŁAW GOLINOWSKI
}

Department of Botany, Institute of Plant Biology, Faculty of Agriculture, Warsaw Agricultural University, Rakowiecka 26/30, 02-528 Warsaw, Poland (Received: December 11, 1986. Accepted: February 16, 1987)

\begin{abstract}
The structure of wheat roots of the "susceptible" variety Capa and "resistant" variety AUS 10894 infested by Heterodera avenae was studied. The processes leading to the formation of syncytia and the range of reactions of the studied varieties to infection are described. In both varieties, necrosis of cells surrounding the nematode, and in the wheat variety AUS 10894, in addition, necrotic changes in cells surrounding syncytia were found. The syncytia formed in the resistant variety degenerated early. The cells adjacent to the syncytia underwent divisions. Cell divisions also took place in the pericycle. They led to the formation of more numerous lateral roots, especially in plants from the susceptible variety. It seems that the earlier degeneration of syncytia and the accompanying necrotic changes in the tissues surrounding the syncytia observed in wheat of the AUS 10894 variety can be taken as signs of host resistance reactions.
\end{abstract}

Key words: nematode, syncytium, necrosis

\section{INTRODUCTION}

Nematodes from the Heteroderidae family are wide-spread parasites of crop plants which exert an unfavorable influence on their growth and yield (Trudgill et al. 1975a, b, Wilski 1977, Evans 1982). This is one of the reasons why numerous, multifaceted studies which may contribute to understanding of the mechanisms of susceptibility and resistance 
of plants to these parasites, are in progress. Detailed studies are being conducted on their development in the roots of various plant species and varieties (Endo 1964, Johnson and Fushtey 1966, Yu and Steele 1981), the structure and function of the syncytia induced by them (Jones and Northcote 1972, Jones 1981a, b, Stender et al. 1982, Rice et al. 1985), and on the changes in host tissues surrounding the nematode and syncytium (Endo 1965, Endo and Veech 1970, Yu and Steele 1981, Rice et al. 1985).

The objective of this study is to establish and compare the type and range of structural changes occurring in the roots of a susceptible and resistant wheat variety infested by Heterodera avenae.

\section{MATERIAL AND METHODS}

The study was carried out on wheat (Triticum aestivum L.) var. Capa (susceptible to Heterodera avenae) and AUS 10894 (resistant). The plants were subjected to infestation by larvae of Heterodera avenae Woll., pathotype Västergötland Vg. 2. Both wheat varieties and the appropriate nematode pathotype for them were obtained through Dr. Christer Magnusson from the Swedish University of Agricultural Science in Uppsala. Wheat grains were sterilized in $3.5 \%$ calcium hypochlorite and germinated on filter paper moistened with distilled water. Seedlings with approx. $1 \mathrm{~cm}$ long roots were transferred to previously scorched sand mixed with soil containing nematode cysts. One $\mathrm{cm}^{3}$ of substratum contained approximately 18 cysts. The substratum intended for control plants was scorched as a whole. The plants were watered with Hoagland's medium. Material for study was sampled from the controls after 14 and 28 days. from plants infested with the nematodes, after 2, 4, 7, 14, 21 and 28 days. The roots were removed from the substratum and rinsed under running tap water, after which approx. $1.5 \mathrm{~mm}$ long fragments were out from them. The choice of the appropriate fragment from the roots of older plants was made easy by the external sings of infestation - thickened regions with numerous lateral roots. In the case of younger plants, a binocular was used. From controls, the root apex, a $1.5 \mathrm{~mm}$ long fragment located immediately behind it and segments from mid-length of the root and from the root base were taken. The samples were fixed in Karnovsky's fixative (1965) at room temperature and postfixed in $1 \% \mathrm{OsO}_{4}$ at $4{ }^{\circ} \mathrm{C}$, then after dehydration in ethanol and propylene oxide, embedded in Spurr synthetic resin. A LKB microtome was used to prepare cross sections $3 \mu \mathrm{m}$ thick, which after staining with Azure and toluidine blue were analysed in a light microscope, and ultrathin sections stained with uranyl acetate and lead citrate, which were analysed in a JEM 100C electron microscope. 


\section{RESULTS}

Invasive Heterodera avenae larvae penetrated into the roots of the susceptible variety Capa, mechanically destroying the cortex and stele cells (Fig. 2). After they passed into a sedentary phase, syncytia were induced in the stele. The syncytia in the Capa variety were very developed. They were situated adjacent to the central metaxylem vessel and took up the space between two or even three successive xylem bundless (Fig. 4). In older roots, they filled the entire central part of the stele and encompassed the central metaxylem vessel, the surrounding thick-walled cells and sometimes even phloem bundles (Fig. 6). Analysis of a series of cross-sections showed that syncytia spread not only laterally, but also along the root axis. It was sometimes found that instead of large syncytia positioned centrally in the stele, smaller ones made up of only several cells arose along its edges. Syncytia arise as the result of dissolution of sections of cell walls and the joining of the protoplasts of neighboring cells (Figs. 3-6). The cells incorporated into syncytia were enlarged, had dense, intensely stained cytoplasms and numerous small vacuoles. Their nuclei had an increased volume and the syncytium cell walls were thinned (Figs. 4, 5).

Seven days after infection, the syncytia had a dense cytoplasm, which contained numerous free and bound to the endoplasmic reticulum ribosomes as well as mitochondria (Figs. 9, 10). The mitochondria were often elongated, narrowed in the middle, which may indicate that they were undergoing division (Fig. 10). Also found in the cytoplasm were plastids with starch grains, dictyosomes and numerous lipid bodies and short cisterns of rough endoplasmic reticulum (Figs. 8, 10, 11). Cell nuclei sometimes assumed an irregular, amoeboid shape (Fig. 9). They were often clustered in the central part of the syncytium (Figs. 6, 9). No divisions of the nuclei were observed. The syncytia contained numerous vacuoles of various size (Fig. 7), filled with a flocculent, osmophilic material, which disappeared with time (Fig. 8). The tonoplast surrounding the vacuoles was often fragmented (Fig. 10), while the plasma membrane always encased the main wall and rounded fragments of the dissolved walls inside of the syncytium (Figs. 8 and 10). On the internal surface of the main cell wall, in the vicinity of vessels, large, terminally distended protuberances were formed (Fig. 11).

In older roots, in addition to normally functioning syncytia, degenerating ones were also observed. After 14 days of infection, an osmophilic, granular material began to accumulate between the plasma membrane and cell wall (Fig. 12). Similar osmophilic granules were also observed in cells adjacent to syncytia (Fig. 13). 


\section{PLATE I}

Changes in root tissues of Capa variety wheat infested with Heterodera avenae Woll. Fig. 1. A cross-section through the mid-length of the root of a control plant. Co - cortical parenchyma, En - endodermia, Pe - pericycle, CMx - central metaxylem vessel. $160 \times$. Fig. 2. A cross-section through a root 4 days after infection. Along the passage way of the nematode (arrow), the cells undergo mechanical damage and necrosis (arrow head).

\section{PLATE II}

Changes in root tissues of Capa variety wheat infested with Heterodera avenae Woll. Figs. 3 and 4. Selected cross-section from a series of slides made through a root 4 days after infection. Fig. 3. Enlarged, thin-walled cells situated next to the central metaxylem vessel are marked by an arrow. An asterisk marks a forming lateral root. $160 \times$. Fig. 4 . A syncytium (S) with visible enlarged nuclei, numerous small vacuoles and fragments of internal walls. The lateral root is marked with an asterisk. $160 \times$. Figs. 5 and 6. Selected cross-sections from a series of slides made through a root 14 days after infection. Fig. 5. A syncytium (S) is located on the edge of the stele. The enlarged, thin-walled cells visible around the central metaxylem vessel (arrow head), will be incorporated into the syncytium. The nematode is marked by an arrow, lateral roots by asterisks. $160 \times$. Fig. 6. Characteristically clustered nuclei (arrow) are visible in the syncytium (S). Endodermis, pericycle and cortical parenchyma cells adjacent to the nematode are undergoing necrosis (arrow head). Lateral roots are marked by asterisks. $160 \times$

PLATE III

The ultrastructure of a syncytium from the root of Capa variety wheat infested with Heterodera avenae Woll. 7 days after infection. Fig. 7. Very numerous, variously sized vacuoles (V) are visible in the syncytium. CW - external cell wall of the syncytium, $\mathrm{N}$ - nucleus, $3400 \times$. Fig. 8. Visible in the cytoplasm of the syncytium are numerous small vacuoles (V), plastids containing starch grains (Pa), mitochondria (Mi), Golgi apparatuses (Ga) and endoplasmic reticulum. A plasma membrane is surrounding a visible part of the internal cell wall $(\mathrm{CW}) .8500 \times$. Fig. 9. A part of the cytoplasm of a syncytium with visible fragments of three adjacent to each other nuclei $(\mathrm{N})$. V - vacuole, $\mathrm{Li}$ - lipids, Mi - mitochondria $10000 \times$

PLATE IV

The ultrastructure of a syncytium from the root of Capa variety wheat infested by Heterodera avenae Woll. 7 days after infection. Fig. 10. The edges of the internal wall (CW) of the syncytium are rounded, surrounded by a plasma membrane. The tonoplast of vacuoles (V) is undergoing fragmentation. Mitochondria (Mi) are undergoing divisions. $\mathrm{Ga}$ - Golgi apparatus, ER - endoplasmic reticulum, Li - lipids. $10000 \times$. Fig. 11. A fragment of the external cell wall $(\mathrm{CW})$ of the syncytium with characteristic protuberances (arrow heads).

$\mathrm{V}$ - vacuole. $\mathrm{Li}$ - lipids. $20000 \times$

\section{PLATE V}

Changes in the roots of Capa variety wheat infested by Heterodera avenae Woll. 14 days after infection. Fig. 12. A fragment of a syncytium. The protoplast is deorganized. An osmophilic, granular material (arrow head) is seen to accumulate between the plasma 


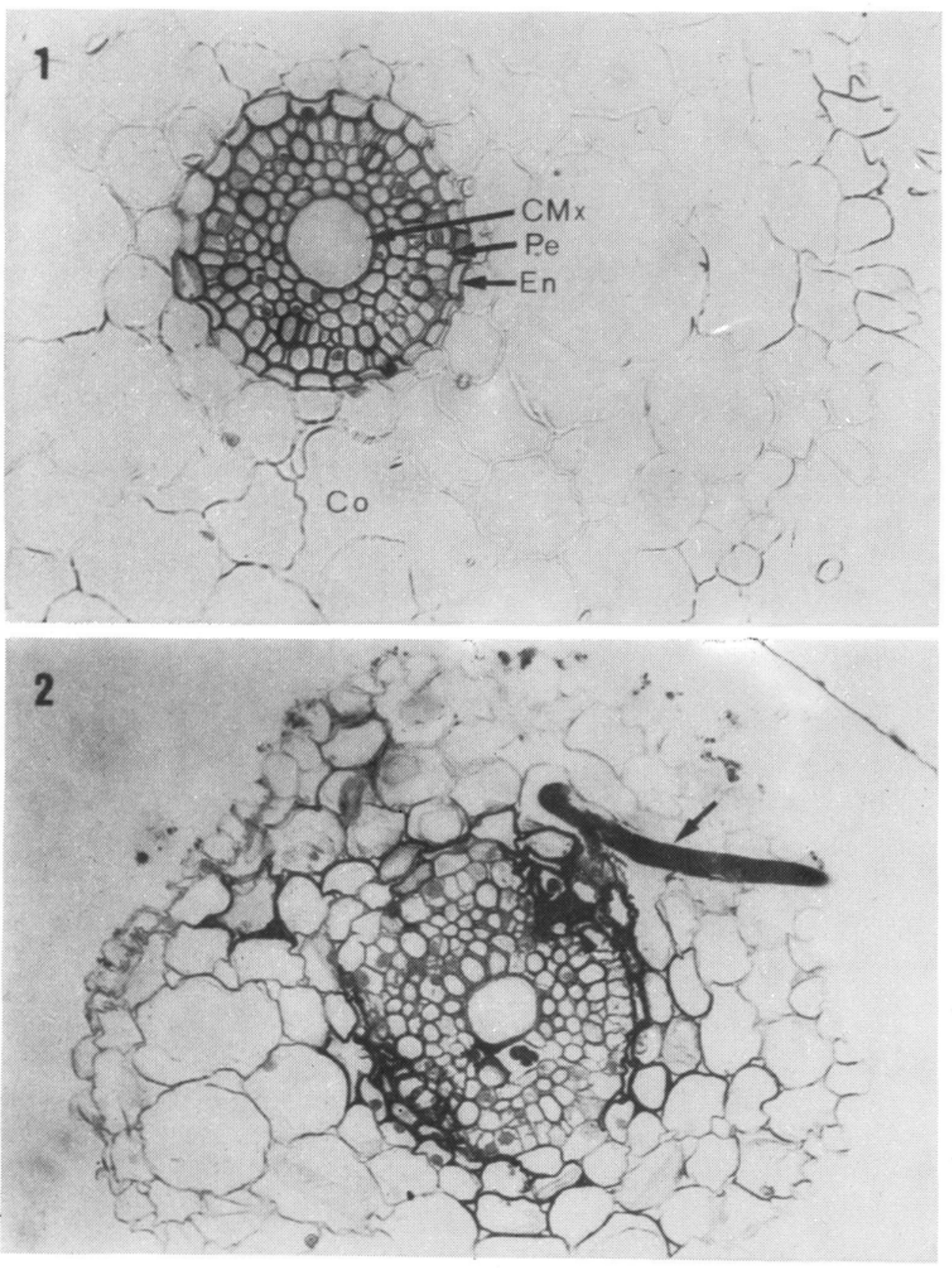




\section{3}

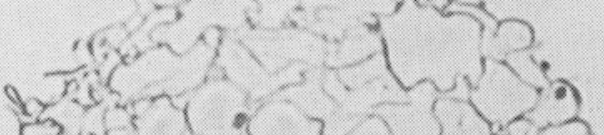

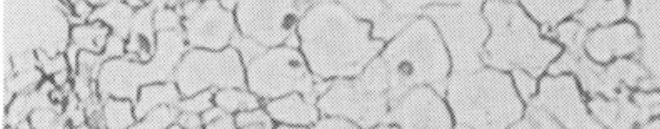

3503003 > 300 कo sogor.

होंड

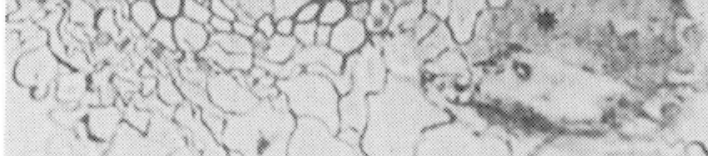
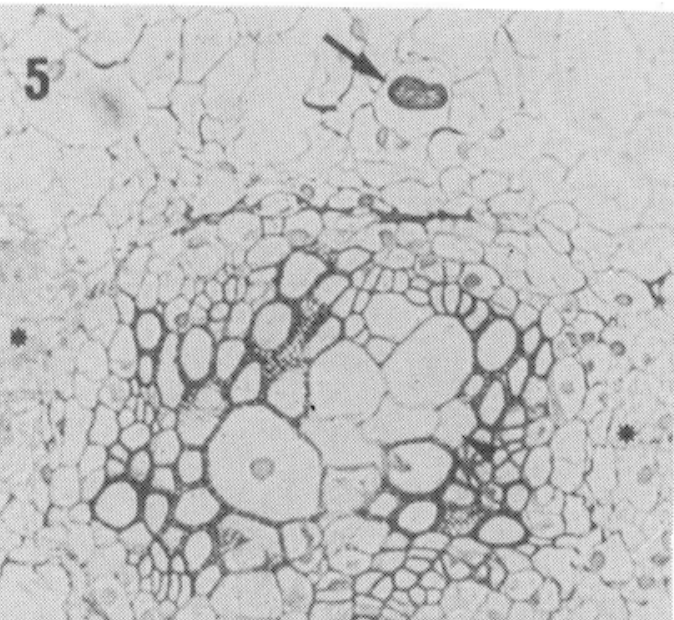

$r-1$. की

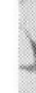
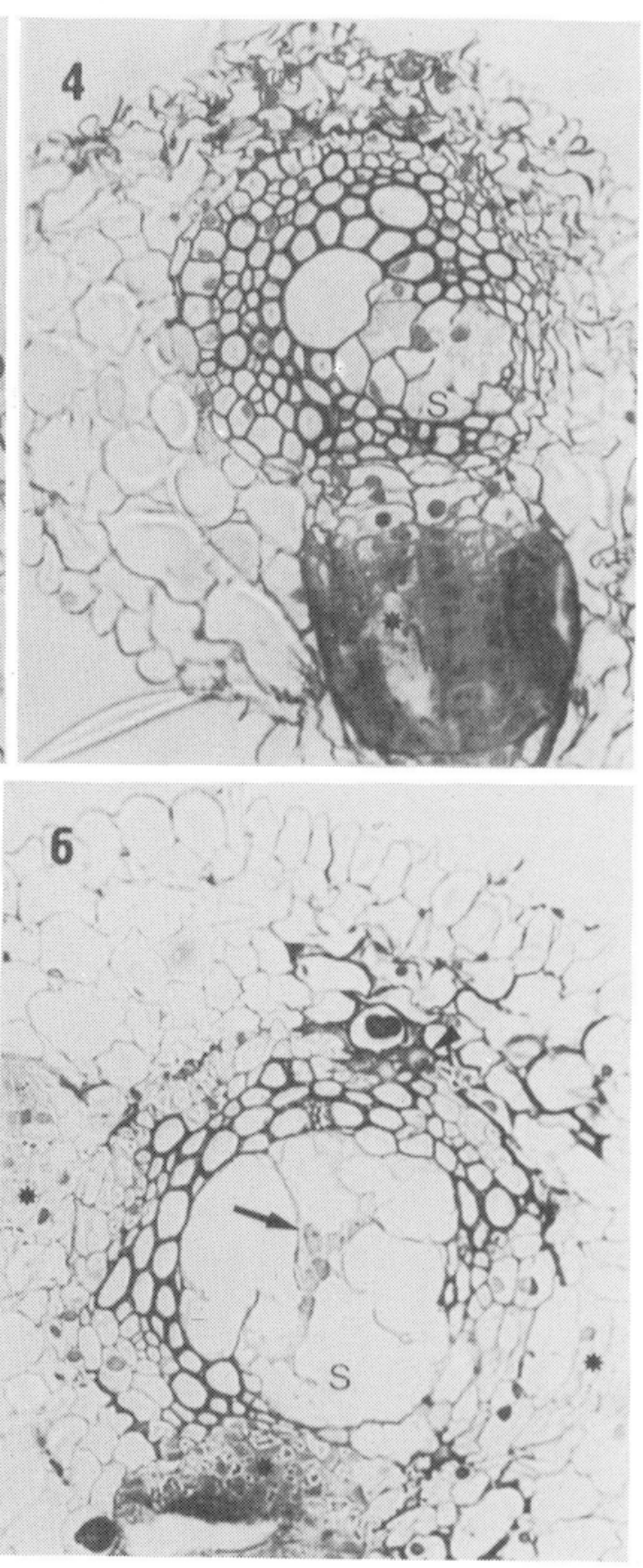
PLATE IV
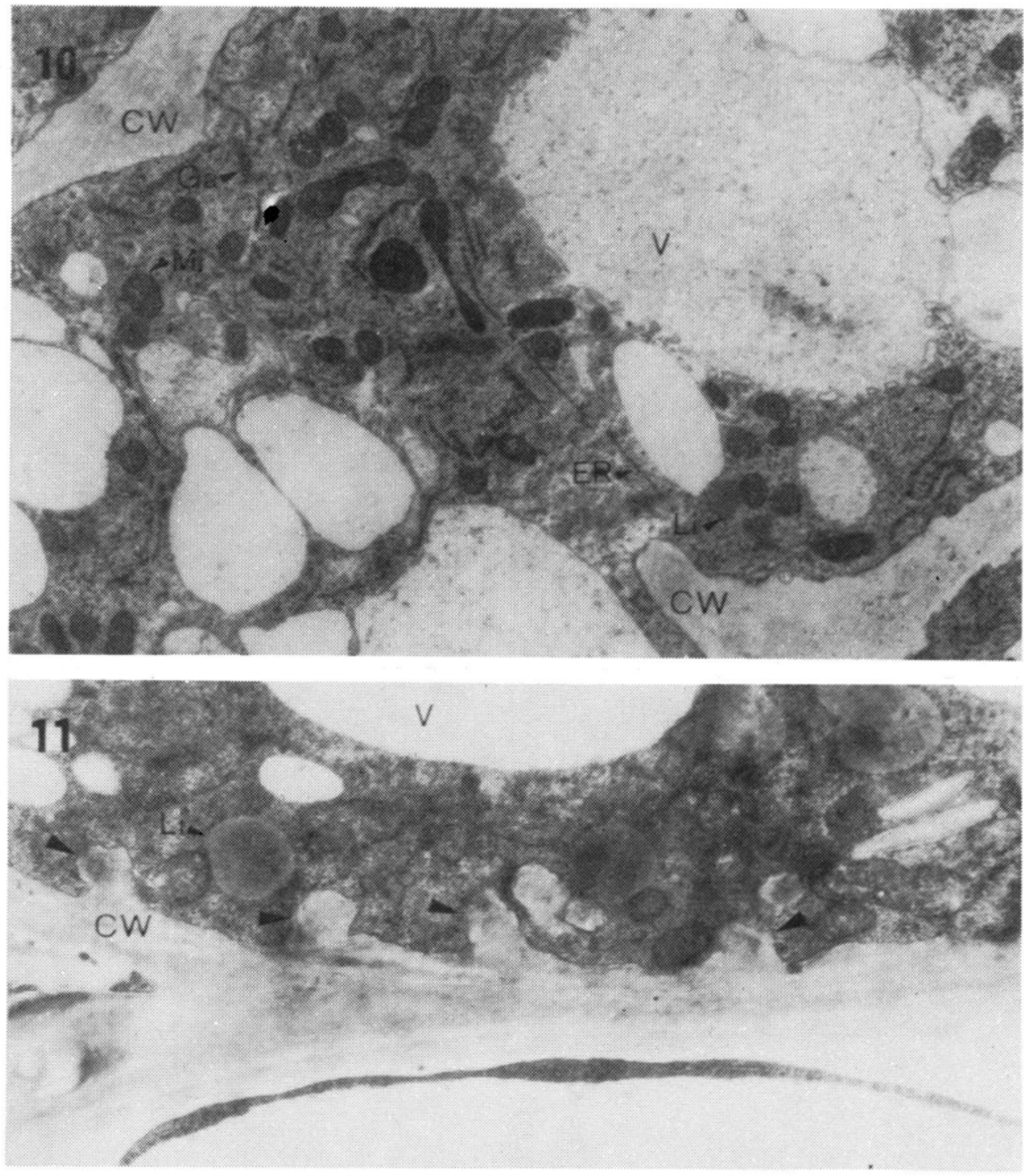
PLATE V
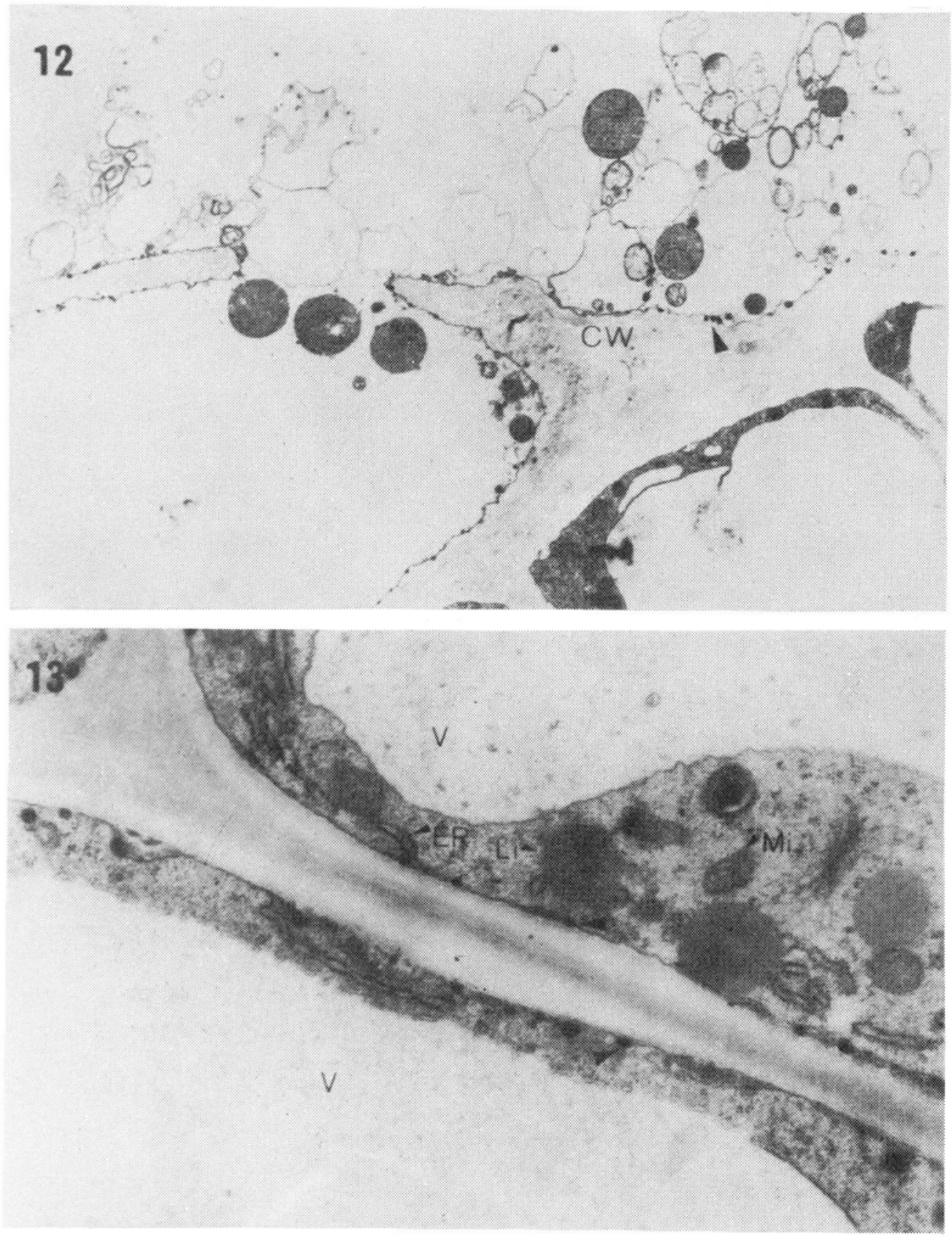

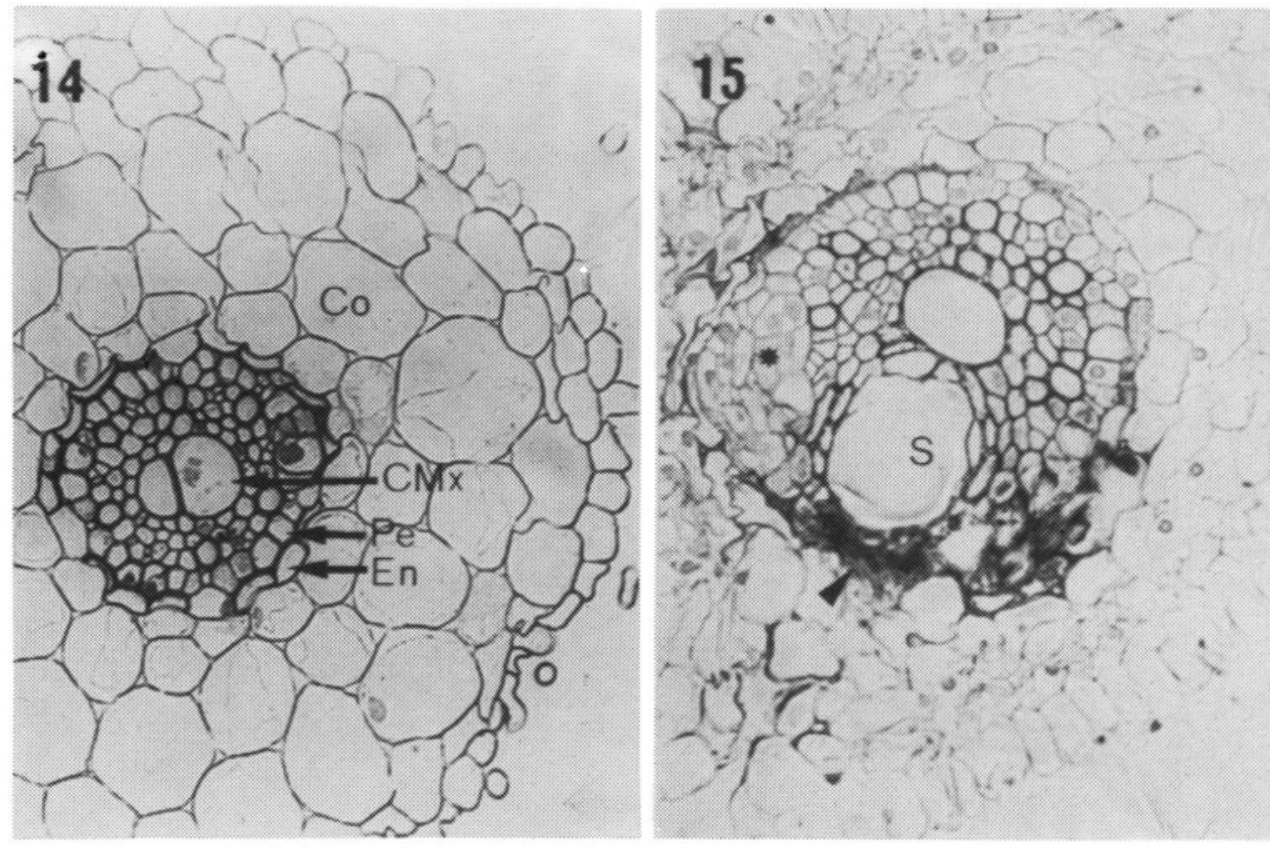

16

$$
\begin{aligned}
& 12 \\
& +\quad 43
\end{aligned}
$$

isto $x$ -

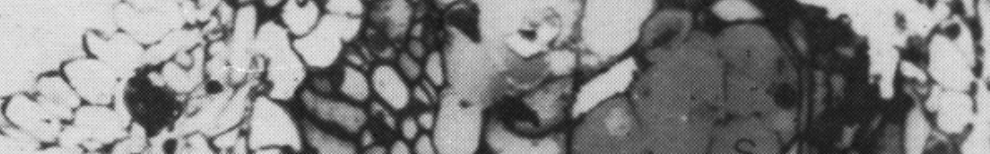

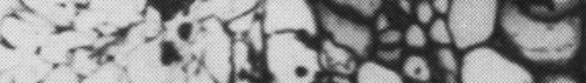

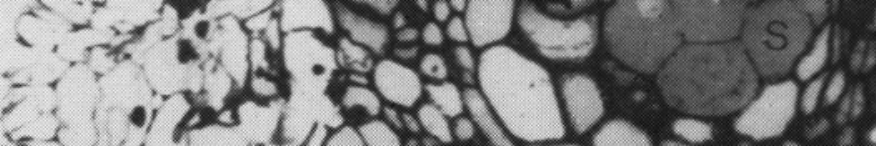
z

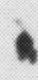
$\therefore$. 

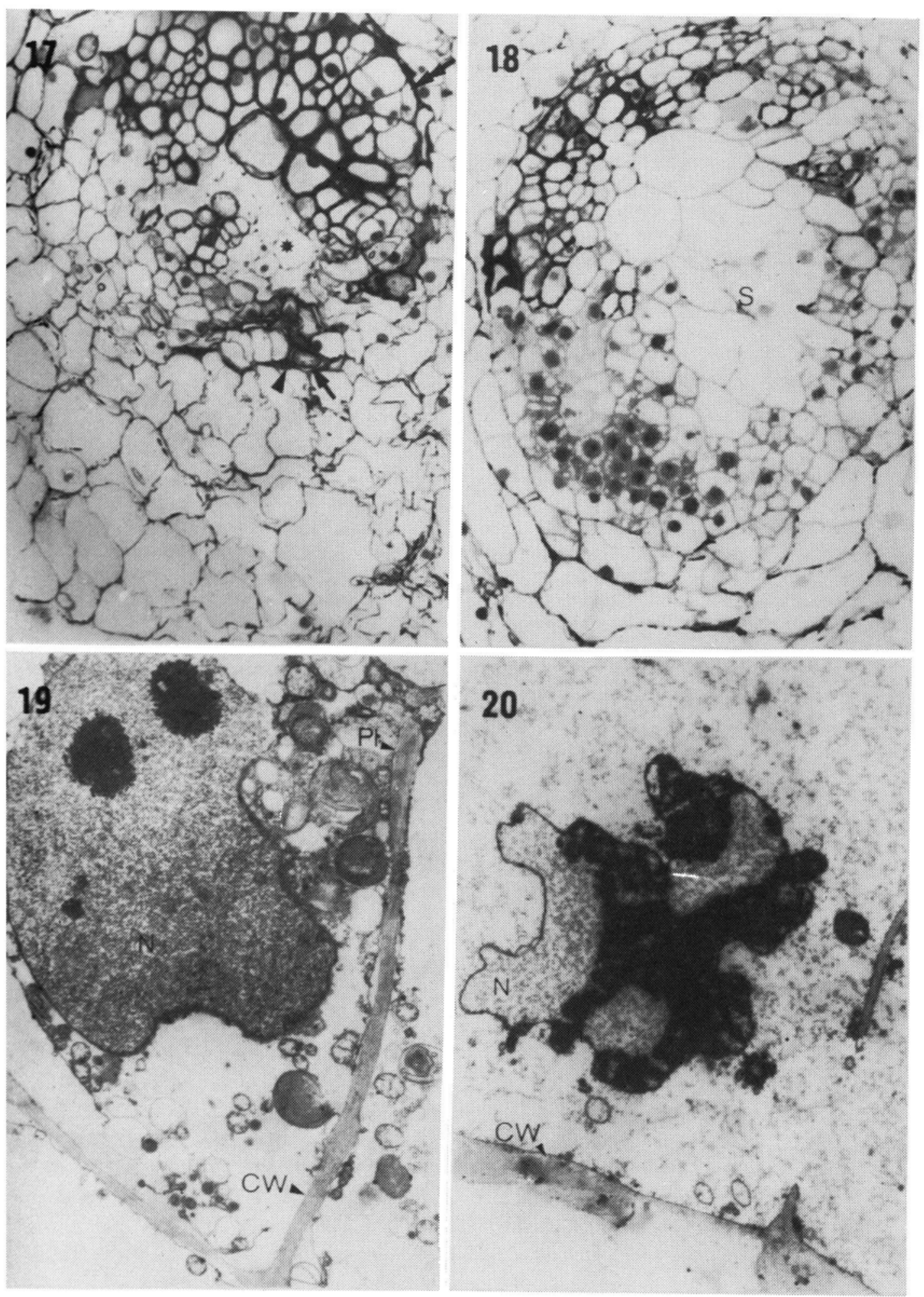
membrane and syncytium wall $(\mathrm{CW}) .6600 \times$. Fig. 13. A fragment of cells adjacent to the syncytium. The osmophilic granules between the plasma membrane and cell wall are marked with arrow heads, $\mathrm{V}$ - vacuole, $\mathrm{Li}$ - lipids, $\mathrm{ER}$ - endoplasmic reticulum, $\mathrm{Mi}$ - mitochondria. $20000 \times$

PLATE VI

Changes in the root tissues of AUS 10894 variety wheat infested by Heterodera avenae Woll. Fig. 14. A cross-section through the mid-length of the root of a control plant. Co - cortical parenchyma, En - endodermis, Pe-pericycle, CMx - central metaxylem vessel. $160 \times$. Fig. 15. A cross-section through a root 14 days after infection. A small syncytium (S) is visible in the stele. An extensive area of necrotized cortex and stele cells is marked by an arrow head. A lateral root is marked by an asterisk. $160 \times$. Fig. 16. A fragment of a cross-section through a root 14 days after infection. The necroses surrounding the syncytium (S) are marked by arrow heads. In the vicinity of the syncytium, in the phloem fields and pericycle, cells are undergoing division. The nematode is marked by

an arrow. $160 \times$

\section{PLATE VII}

Changes in roots of AUS 10894 variety wheat infested by Heterodera avenae Woll. Figs. 17 and 18. Cross-sections through roots 21 days after infection. Fig. 17. The area of necrotic cells surrounding the nematode (arrow) is marked by an arrow head. Pericycle cells are undergoing divisions (double arrow). A significant part of the stele is taken up by large, thin-walled cells (asterisk). $160 \times$. Fig. 18. A developed syncytium (S) is surrounded by parenchymal regenerative tissue. $160 \times$. Figs. 19 and 20. Degenerative changes in syncytia in roots of AUS 10894 wheat. Fig. 19. A syncytium in a root 7 days after infection. The protoplast is deorganized to a high degree. The plasma membrane along the syncytium cell wall $(\mathrm{CW})$ is disrupted. $\mathrm{N}$ - nucleus. $5600 \times$. Fig. 20. A fragment of a syncytium from a root 14 days after infection. The nucleus $(\mathrm{N})$ has an irregular shape. The chromatin is packed, intensely stained. CW - syncytium cell wall. $5600 \times$

In addition to mechanical damage to cells caused by the passage of the nematode and changes connected directly with the formation of syncytia, symptoms of necrosis of tissues were also observed in the roots of this variety of wheat. The necrotic changes were, however, not very extensive. They were most often limited only to the cells nearest to the nematode (Figs. 2, 6). Necrosis accompanying developing syncytia was not found.

The pericycle cells of Capa variety wheat are usually enlarged and undergo division giving rise to lateral roots (Fig. 4). Sometimes, three or even four lateral roots are formed simultaneously on the same level (Fig. 6).

Heterodera avenae larvae also attack the roots of the resistant wheat variety, AUS 10894. Mechanical injury to cells was observed in the 
tissues through which the nematodes passed. The cells surrounding the nematode where it settled underwent necrosis. Extensive necroses accompanying the nematodes were observed in the cortical parenchyma, endodermis, pericycle and inside the stele (Fig. 17). Inside the stele, under the influence of nematodes, syncytia, sometimes very widespread, were formed (Figs. 16, 18). The contents of some of them, however, underwent early degradation (Figs. 19, 20). Other profound changes also occurred in the stele in those root segments where syncytia were formed (Figs. 15, 16, 17 and 18). The tissues surrounding the syncytia underwent necrosis (Figs. 15, 16). They were extensive and not always involved with the immediate closeness of nematodes. In older roots, along the walls of syncytia and also some distance from them, numerous clusters of small cells were also observed (Fig. 16). The regular, row-like arrangement of these cells indicates that they were undergoing divisions. Cell divisions also took place in phloem bundles and in the pericycle (Figs. 15, 16, 17). The arrangement of the remaining tissues of the stele was thoroughly changed as the result of pressure from expanding syncytia and newly arising cells.

\section{DISCUSSION}

The syncytia induced by Heterodera avenae in the roots of both studied wheat varieties formed and expanded in a way typical for syncytia formed in plant roots by cyst-nematodes (Johnson and Fushtey 1966, Jones and Northcote 1972, Wyss et al. 1984). The fully developed, normally functioning syncytia observed in the roots of the susceptible variety, Capa, had an ultrastructure similar to that of the syncytia, described in literature, arising in the roots of other susceptible plants (Jones and Northcote 1972, Jones 1981a, b, Stender et al. 1982, Wyss et al. 1984). The protuberances observed on the walls of the syncytia in the neighborhood of vessels were also observed in rape infested by Heterodera schachtii (Stender et al. 1982) and soy subjected to Heterodera glycines and in giant cells induced in this species by Meloidogyne incognita (Jones and Dropkin 1975), as well as in a susceptible form of Raphanus sativus infected by Heterodera schachtii (Wyss et al. 1984). According to Jones and Northcote (1972), syncytia induced by representatives of the genus Heterodera and the giant cells arising under the influence of Meloidogyne incognita are a form of multinucleate transfer cells. The protuberances on the walls of syncytia increase the ratio of protoplast area to volume and play a role in intense, selective transport over short distances.

Plants susceptible and resistant to nematode infection react to infestation 
in different ways. The parasites attain full maturity in the roots of susceptible hosts, and the development of the syncytia induced by them procedes unhindered. However, in resistant hosts, early death of larvae and degeneration of syncytia is a common phenomenon (Endo 1965, Y u and Steele 1981, Wyss et al. 1984, Rice et al. 1985), found also in the wheat variety AUS 10894. The tissues neighboring syncytia in resistant plants may, to a greater or lesser extent, undergo necrosis (Endo 1965, Rice et al. 1985). According to Endo and Veech (1970), necroses accompanying the syncytia induced by Heterodera glycines in the roots of resistant soy, are an active mechanism intended to restrict the development of the syncytium, and thus, of the nematodes. Dropkin (1969) also indicates that the necrotic reaction is connected with certain, although not all, types of genetic resistance to nematodes, especially to the genera Heterodera and Meloidogyne. The early degeneration of syncytia and necrotic changes which occur to a wide extent around the syncytia in AUS 10894, in the face of their lack in Capa variety wheat may also, it seems, be taken to be evidence of resistance mechanisms of the resistant host. The spaces formed in root tissues in the place of the degenerated syncytia, are filled in both resistant and susceptible plants, by a regenerative parenchymatic tissue (Endo 1965, Yu and Steele 1981). Cell divisions leading to the formation of such a tissue were also observed in variety AUS 10894. The stimulation of division of pericycle cells leading to the formation of more numerous lateral roots, observed in sites of infection in both studied varieties, is probably the effect of the presence of nematodes and syncytia. According to Wilski (1977), the thickenings on the roots with the numerous lateral roots are one of the symptoms of infection of plants by Heterodera avenae, which may be the result of the stimulatory effect of nematode larvae (Yu and Steele 1981).

Acknowledgment

This study was conducted within the framework of CPBP 05.02.

\section{REFERENCES}

Dropkin V. H., 1969. Cellular responses of plants to nematode infections. Ann. Rev. Phytopathol. 7: 101-122.

Endo B. Y., 1964. Penetration and development of Heterodera glycines in soybean roots and related anatomical changes. Phytopathology 54: 79-88.

Endo B. Y., 1965. Histological responses of resistant and susceptible soybean varieties and backcross progeny to entry and development of Heterodera glycines. Phytopathology 55: $375-381$.

Endo B. Y., Veech J. A., 1970. Morphology and histochemistry of soybean roots infected with Heterodera glycines. Phytopathology 60: 1493-1498. 
Evans K., 1982. Effects of infestation with Globodera rostochiensis (Wollenweber) Behrens Ro 1 on the growth of four potato cultivars. Crop Protection 1: 169-179.

Johnson P. W., Fushtey S. G., 1966. The biology of the oat cyst nematode Heterodera avenae in Canada. II. Nematode development and related anatomical changes in roots of oast and corn. Nematologica 12: 630-636.

Jones M. G. K., 1981a. The development and function of plant cells modified endoparasitic nematodes. In: Plant parasitic nematodes, Zuckerman B. M., Rhode R. A. (eds.), Academic Press, New York, Vol. III: pp. 255-279.

Jones M. G. K., 1981b. Host cell responses to endoparasitic nematode attack: structure and function of giant cells and syncytia. Ann. Appl. Biol. 97: 353-372.

Jones M. G. K., Dropkin N. H., 1975. Cellular alterations induced in soybean roots by three endoparasitic nematodes. Physiol. Plant Pathol. 5: 119-124.

Jones M. G. K., Northcote D. H., 1972. Nematode-induced syncytium - a multinucleate transfer cell. J. Cell. Sci. 10: 789-809.

Karnovsky M. J., 1965. A formaldehyde-glutaraldehyde fixative of high osmolality for use in electron microscopy. J. Cell. Biol. 25: 137A.

Rice S. L., Leadbeater B. S. C., Stone A. R., 1985. Changes in cell structure in roots of resistant potatoes parasited by potato cyst-nematodes. I. Potatoes with resistance gene $\mathrm{H}_{1}$ derived from Solanum tuberosum ssp. andigena. Physiol. Plant Pathol. 27: 219-234.

Stender C., Lehmann H., Wyss U., 1982. Feinstrukturelle Untersuchungen zur Entwicklung von Wurzel-Riesenzellen (Syncytien) induziert durch den Rübenzystennematoden Heterodera schachtii. Flora 172: 223-233.

Trudgill D. L., Evans K., Parrott D. M., 1975a. Effects of potato cyst-nematodes on potato plants. I. Effects in a trial with irrigation and fumigation on the growth and nitrogen and potassium contents of a resistant and susceptible variety. Nematologica 21: $169-182$.

Trudgill D. L., Evans K., Parrott D. M., 1975b. Effects of potato cyst-nematodes on potato plants. II. Effects on haulm size, concentration of nutrients in haulm tissue and tuber yield of a nematode resistant and a nematode susceptible potato variety. Nematologica 21: 183-191.

Wilski A., 1977. Mątwik zbożowy (Heterodera avenae Woll., 1924). PAN, Komitet Ochrony Roślin.

Wyss U., Stender C., Lehmann H., 1984. Ultrastructure of feeding sites of the cyst nematode Heterodera schachtii Schmidt in roots of susceptible and resistant Raphanus sativus var. oleiformis pers. cultivars. Physiol. Plant Pathol. 25: 21-37.

Yu M. H., Steele A. E., 1981. Host-parasite interaction of resistant sugarbeet and Heterodera schachtii. J. Nematol. 13: 206-212.

\section{Zmiany w strukturze korzeni pszenicy (Triticum aestivum L.)} roślin podatnych $i$ odpornych na porażenie mątwikiem zbożowym (Heterodera avenae Woll.)

\section{Streszczenie}

Badano strukturę korzeni pszenicy "podatnej” odmiany Capa i odmiany "odpornej” AUS 10894 porażonych przez mątwika zbożowego. Opisano przebieg procesów prowadzących do powstania syncytiów, a także zakres reakcji badanych odmian roślin na infekcję. 
U obu odmian stwierdzono nekrotyczną reakcję komórek otaczających ciało nicienia, a u pszenicy odmiany AUS 10894 ponadto zmiany nekrotyczne w tkankach otaczających syncytia. Syncytia formowane u odmiany odpornej wcześnie degenerowały. Przylegające do syncytiów komórki podlegały podziałom. Podziały komórek miały również miejsce w perycyklu. Prowadziły one do powstania liczniejszych korzeni bocznych, zwłaszcza u roślin odmiany podatnej na porażenie. Wydaje się, że wcześniejsza dezintegracja syncytiów oraz towarzyszące syncytiom zmiany nekrotyczne w otaczających je tkankach obserwowane u pszenicy odmiany AUS 10894 można uznać za przejawy działania mechanizmów obronnych odpornego gospodarza. 